\title{
External costs of electricity generation in 27 European countries from 2010 - 2030: Pathway towards sustainability or business as usual?
}

Frank Baumgärtner

RWTH Aachen

Peter Letmathe ( $\sim$ Peter.Letmathe@rwth-aachen.de )

RWTH Aachen University https://orcid.org/0000-0003-4961-2852

Keywords:

Posted Date: April 29th, 2021

DOl: https://doi.org/10.21203/rs.3.rs-385342/v1

License: (c) (i) This work is licensed under a Creative Commons Attribution 4.0 International License.

Read Full License 


\section{Abstract}

The authors have requested that this preprint be removed from Research Square. 